Article

\title{
Flooding Related Consequences of Climate Change on Canadian Cities and Flow Regulation Infrastructure
}

\author{
Ayushi Gaur ${ }^{1}$, Abhishek Gaur ${ }^{2, *}$, Dai Yamazaki ${ }^{3}$ and Slobodan P. Simonovic ${ }^{1}$ \\ 1 Facility for Intelligent Decision Support, Department of Civil and Environmental Engineering, \\ Western University, London, ON N6A 3K7, Canada; ayushigaur.evs@gmail.com (A.G.); \\ simonovic@uwo.ca (S.P.S.) \\ 2 National Research Council Canada, 1200 Montreal Road, Ottawa, ON K1A 0R6, Canada \\ 3 Institute of Industrial Science, The University of Tokyo, Meguro-ku, Tokyo 153-8505, Japan; \\ yamadai@rainbow.iis.u-tokyo.ac.jp \\ * Correspondence: Abhishek.Gaur@nrc-cnrc.gc.ca; Tel.: +1-613-998 9799
}

Received: 26 October 2018; Accepted: 27 December 2018; Published: 1 January 2019

\begin{abstract}
This study discusses the flooding related consequences of climate change on most populous Canadian cities and flow regulation infrastructure (FRI). The discussion is based on the aggregated results of historical and projected future flooding frequencies and flood timing as generated by Canada-wide hydrodynamic modelling in a previous study. Impact assessment on 100 most populous Canadian cities indicate that future flooding frequencies in some of the most populous cities such as Toronto and Montreal can be expected to increase from 100 (250) years to 15 (22) years by the end of the 21st century making these cities highest at risk to projected changes in flooding frequencies as a consequence of climate change. Overall $40-60 \%$ of the analyzed cities are found to be associated with future increases in flooding frequencies and associated increases in flood hazard and flood risk. The flooding related impacts of climate change on 1072 FRIs located across Canada are assessed both in terms of projected changes in future flooding frequencies and changes in flood timings. Results suggest that $40-50 \%$ of the FRIs especially those located in southern Ontario, western coastal regions, and northern regions of Canada can be expected to experience future increases in flooding frequencies. FRIs located in many of these regions are also projected to experience future changes in flood timing underlining that operating rules for those FRIs may need to be reassessed to make them resilient to changing climate.
\end{abstract}

Keywords: climate change; flood hazard; flood risk; return period; streamflow regulation rules; Canada

\section{Introduction}

Due to consistent warming of Earth's climate particularly in the recent decades, weather elements and their extremes have become more severe and frequent, with increases in extreme heat, intense precipitation, drought, and flooding recorded across the globe [1,2]. Floods are the most frequently occurring natural hazard in Canada and are shaped by one or more hydrologic processes such as snowmelt and ice jams, hydro-meteorological factors such as short duration intense rainfall, rain on snow, or structural failures such as dam breaks $[3,4]$.

Evidences of shifts in extreme flow characteristics have been recorded in different regions of Canada. Trends in the flow extremes for 248 catchments in Canada were examined by Burn et al. [5]. Decreasing trends in annual maximum flows were obtained for catchments located in southern Canada and increasing trends were obtained for catchments located in northern Canada. Springtime and 
summer runoff characteristics were examined by Burn et al. [6] for stations located in the Canadian prairies and obtained decreasing trends in spring snowmelt runoff volume and peak flows, and an earlier occurrence of the flooding events. Changes in the peak flow timings among rivers located in the western Canada over the time-period: 1960-2006 were analyzed by Dery et al. [7]. An earlier onset of spring melt, decrease in summer streamflow, and delay in the onset of enhanced autumn flows were obtained in most of the analyzed rivers. Flow trends at 68 gauging stations with at least 50 years of flow records were analyzed by Burn et al. [8], and more trends than to be expected by chance were found. They noted decreasing trends in annual and spring maximum flows and an earlier shift in the timing of the flooding events. Increasing magnitudes and frequencies of extreme floods has affected Canadian cities and population therein. Indeed, severe flooding events have been recorded in some of the most populous Canadian cities in the recent years such as: Montreal in 2017 and 2012, Thunder Bay in 2012, Calgary in 2013 and 2010, Winnipeg in 2009, and Toronto in 2005 and 2013 [9]. The enormous costs of Calgary floods in 2013 (over \$5 billion) and Toronto floods in 2005 (\$587 million) and 2013 ( $\$ 1.2$ billion) provide some examples of costs associated with urban flooding in Canada.

A number of approaches have been used to simulate flood magnitudes and assess flooding frequencies in catchments across the globe. Gaur et al. [10] assessed projected future changes in flood hazard for the Grand River basin, Canada by generating flows at the catchment outlet using WatFlood hydrologic model and by fitting a Generalized Pareto distribution (GPD) on the peak-over-threshold values of simulated flooding events. Fiorentino et al. [11] and Gioia et al. [12] demonstrated the use of spatially discrete parameters in theoretically derived distributions and analytical models to more accurately perform regional flood frequency analysis in Italy. Devkota and Gyawali [13] assessed the impacts of climate change on the Koshi River basin in Nepal by using bias-corrected climate forecasts from two Regional Climate Models (RCMs) and performing hydrological simulations using the SWAT model. Qin and Lu [14] assessed projected future changes in flooding frequencies for the Heshui watershed in China. A coupled Long Ashton Research Station Weather Generator (LARS-WG) and Semi-distributed Land Use-Based Runoff Processes (SLURP) approach was used to generate future flows, which were then fitted to Pearson type III distribution to perform flood frequency analysis. Das et al. [15] evaluated the suitability of three extreme value distributions: Gumbel, Log-Pearson type 3, and Generalized Extreme Value (GEV) in modelling flood extremes and recommended the use of GEV for climate change impact assessments.

Long-term forecasts of flood-hazard and flood-risk have been made at national and continental scales have been made [16-22]. For instance, future changes in flood hazard across Europe was assessed by dynamically downscaling future climatic projections from two regional climate models (RCMs) and performing hydrologic modelling using LISFLOOD model [23]. Streamflow was generated for historical (1961-1990) and future (2061-2100) timelines and an assessment of projected changes in flood magnitudes of 100 year return period floods was performed. It was estimated that the recurrence interval of the present day 100-year flood event might decrease to 50 years or less in many parts of Europe in the future. Yamazaki et al. [22] used coarse resolution runoff simulations from the GCMs and simulated higher resolution water levels across the Amazon River basin using CaMa-Flood hydrodynamic model. Hirabayashi et al. [20] assessed future changes in global flood hazard under projected climate change influences using runoff projections from 11 Global Climate Models (GCMs) and CaMa-Flood hydrodynamic model [24]. In Gaur et al. [16] a similar assessment to Hirabayashi et al. [20] was performed for the Canadian landmass but taking into consideration a larger ensemble of runoff projections made by 21 CMIP5 GCMs.

While information on the distribution of flood hazard at a national to global scales is extremely valuable, knowledge about how it is distributed with reference to the population, and built assets is of critical importance to water resource managers, city planners, and policy-makers. Typically flood hazard is combined with an exposure of interest to calculate flood risk. Several techniques have been used in the past to assess flood risk at national to global scales. Hirabayashi et al. [20] for instance quantified global flood exposure by combining gridded population information with the gridded 
flooded area modelled using the CaMa-Flood model. Jongman et al. [25] demonstrated two methods to assess damages caused by flooding at a global scale. In the first method, the economic damage caused by floods for a particular country was calculated by combining information on the population exposed to flooding and GDP per capita of the country whereas in the second method, it was calculated by finding the total urban area exposed to flooding and combining it with the information on maximum damage per square meter for the country. Peduzzi et al. [26] evaluated a Disaster Risk Index by combining the hazards such as floods, droughts, cyclones, and earthquakes with gridded population to assess the human exposure to these hazards at a global scale. De Moel et al. [27] evaluated historical and projected future changes in flood exposure by overlaying information on the distribution of historical and projected future flood depths with the distribution of the urban agglomerations in the Netherlands. Kleinen and Petschel-Held [28] summed the population living in river basins across the globe where the return period of historical 50-year return period event is projected to reduce as a consequence of climate change. Feyen et al. [29,30] combined flood frequency curves with flood depth-damage functions to estimate current and future average annual damage in Europe.

The objective of this study is to use the historical and projected future flood characteristics simulated in Gaur et al. [16], and quantify the risk the projected changes pose to the Canadian population, and the network of flow regulation infrastructure (FRI) existing in Canada. A novel methodology to quantify and demonstrate this risk has been presented in this study using which cities and FRIs most at risk from projected changes in flooding frequencies and timings have been identified. To the best of our knowledge, an assessment of this scale has not been presented before for the Canadian cities and FRIs highlighting the novelty of both the adopted methodology and generated results. The discussion presented in this study will help water resource managers and policymakers to formulate flood management guidelines in Canada.

The rest of the paper is organized as follows. Description of the methodology used for estimating changes in flood hazard and flood risk at Canadian cities and regulated flow gauging stations is provided in Section 2. This is followed by a description of the study region and datasets used in Section 3. Results and discussion are provided in Section 4, followed by conclusions in Section 5.

\section{Methodology}

In Gaur et al. [16] future flow projections were made for the entire Canadian landmass at $\sim 25 \mathrm{~km}$ spatial resolution by adopting an approach used in previous studies at other locations [20,22]. A large ensemble of runoff projections from 21 GCMs were used to obtain flood characteristics across Canada under four different Representative Concentration Pathways (RCPs): RCP 2.6, RCP 4.5, RCP 6.0, and RCP 8.5 [31] for historical (1961-2005) and future (2061-2100) timelines. The projected future changes in flooding frequencies of historical 100 year and 250 year return period events were calculated along with the changes in the timing of the floods. The results were discussed in terms of the aggregated projected changes and associated uncertainty contributed by different GCMs.

The aggregation of the projected changes for a particular RCP was performed using two approaches: (1) all GCM median approach where median of the changes projected by all GCMs was considered as the aggregated change, and (2) robust GCM median approach where median of the projected changes made only by the robust GCMs was considered as the aggregated change. When applying the robust GCM median approach to aggregate projected flooding frequency changes, robust projections were considered as the ones whose projected sign of change was concurred upon by more than $50 \%$ (or the majority) of the GCMs. In the case of flood timing, the robust projections were considered as the ones whose month of flood timing was concurred upon by more than $50 \%$ of the GCMs considered. More details on the methodology used to prepare the aggregated projections can be obtained from Gaur et al. [16].

In this study, the aggregated results from Gaur et al. [16] are used to investigate the flooding related consequences of climate change on 100 most populous Canadian cities and 1072 Flow Regulation Infrastructure (FRI) located in Canada. 


\subsection{CaMa-Flood Hydrodynamic Model}

CaMa-Flood [22,24,32] is a global scale distributed hydrodynamic model that routes input runoff generated by a land surface model to oceans or inland seas along a prescribed river network map. Water storage is calculated at every time-step, whereas variables such as: water level, inundated area, river discharge, and flow velocity, are diagnosed from the calculated water storage. River discharge and flow velocity are estimated using local inertial equation. Floodplain inundation is modelled by taking into consideration sub-grid scale variabilities in river channel and floodplain topography. A river channel reservoir has three parameters: channel length $(L)$, channel width $(W)$, and bank height $(B)$. The floodplain reservoir has a parameter for unit catchment area $\left(\mathrm{A}_{\mathrm{c}}\right)$, and a floodplain elevation profile which describes floodplain water depth $D_{f}$ as a function of flooded area $A_{f}$. The topography related parameters i.e., surface altitude $(\mathrm{Z})$, distance to downstream cell $(\mathrm{X})$, and unit catchment area $\left(\mathrm{A}_{c}\right)$ that are calculated using the Flexible Location of Waterways (FLOW) method [32]. Finally, a Manning's roughness coefficient parameter (n) is used to represent the roughness in the river channel.

The CaMa-Flood model has been validated extensively for its ability to simulate runoff in some of the largest catchments of the globe including the Amazon, Mississippi, Parana, Niger, Congo, Ob, Ganges, Lena, and Mekong $[22,24,33]$. Given the high credibility of the model in simulating river flow and flood inundation dynamics, the model has been used to assess the impacts of climate change at regional to global scales $[19,20,33-36]$. This study uses the globally calibrated version of Cama-Flood model that was used to generate global scale runoff projections in Hirabayashi et al. [20].

\subsection{Future Projected Changes in Flood Risk in Canadian Cities}

The projected future changes in flood risk are calculated for the Canadian cities by combining the projected future changes in flood hazard and population exposed to flooding at the selected cities. Flood hazard is expressed as a function of the magnitude of the projected changes in the flooding frequencies at the city locations. The population exposed to flooding is calculated from flooded area estimates obtained from the results of a retrospective CaMa-Flood simulation.

\subsubsection{Projected Changes in Flood Hazard}

In this study, the projected future changes in the frequencies of historical 100-year and 250-year flooding events are used to define future changes in flood hazard for the cities. Future return periods of historical 100-year and 250-year return period flows were obtained in Gaur et al. [20] by first estimating the historical flood magnitudes corresponding to 100-year and 250-year return periods. This is done by fitting a Generalized Extreme Value (GEV) distribution on annual maximum historical flows $\left(G E V_{h i s, f}\right)$. Next, a GEV distribution is fitted on the annual maximum projected future flows $\left(G E V_{f u t, f}\right)$. Thereafter, future return periods of historical 100-year and 250-year return period flows are estimated by using applying the inverse of $G E V_{\text {fut, }}$ function on historical 100-year and 250-year flow magnitudes. The aggregated results from both all GCM median and robust GCM median methods obtained in Gaur et al. [20] are extracted for grids encompassing the selected city domains, and used to calculate projected changes in flood hazard using Equation (1).

$$
\Delta \mathrm{FH}_{\mathrm{c}}=\frac{\left(\mathrm{RP}_{\mathrm{c}, \mathrm{h}}-\mathrm{RP}_{\mathrm{c}, \mathrm{f}}\right)}{\max \left(\mathrm{RP}_{\mathrm{c}, \mathrm{f}}\right)-\min \left(\mathrm{RP}_{\mathrm{c}, \mathrm{f}}\right)}
$$

where $\Delta \mathrm{FH}_{\mathrm{c}}$ denotes the flood hazard index that depends on the values of projected changes in flood hazard projected between historical (h) and future (f) timelines at city c, RP denotes the return-period of the floods analyzed, and max ( $\mathrm{min}$ ) represent the maximum (minimum) values of return periods among the selected cities. 


\subsubsection{Population Exposed to Flooding}

The total population exposed to flooding is calculated by performing a retrospective simulation of CaMa-Flood following previous studies [20,25]. Following steps are performed:

- A retrospective simulation of a land surface model MATSIRO [37] forced by climate variables obtained from gauges and reanalysis datasets, and with CaMa-Flood river routing is performed for the time-period 1979-2010 for the entire Canadian landmass at $0.005^{\circ}$ spatial resolution to simulate daily discharges, water levels and other flood inundation related variables. The estimated discharge and hydrologic variables from this retrospective run has been validated against observations from Gravity Recovery and Climate Experiment (GRACE) based terrestrial water storage data in Kim et al. [38].

- The annual maximum discharge and water levels obtained from this retrospective run are fitted to a Generalized Extreme Value (GEV) distribution and their 100 and 250 year return period estimates are obtained.

- The water levels corresponding to 100 and 250 year return period flooding events are used to obtain the fraction of CaMa-Flood grids encompassing different cities that are flooded as a consequence of these events.

- The flooded area fraction is then multiplied to the total population of the cities to obtain the total population exposed to flooding.

\subsubsection{Projected Changes in Flood Risk}

The normalized aggregated changes in flood-hazard $\Delta \mathrm{FH}_{\mathrm{c}}$ projected for the cities are multiplied with the normalized log of population exposed to flooding $\left(\mathrm{P}_{f}\right)$ to calculate future projected changes in flooding risk in terms of flood risk index $\Delta \mathrm{FR}_{\mathrm{c}}$ as described in Equation (2).

$$
\Delta \mathrm{FR}_{\mathrm{c}}=\Delta \mathrm{FH}_{\mathrm{c}} \times \frac{\ln \mathrm{P}_{f}-\min \left(\ln \mathrm{P}_{f}\right)}{\max \left(\ln \mathrm{P}_{f}\right)-\min \left(\ln \mathrm{P}_{f}\right)}
$$

\subsection{Future Changes in Flood Hazard at Flow Regulation Infrastructure Locations in Canada}

The Flow Regulation Infrastructure (FRI) are sensitive to both the magnitudes and timings of flooding events. Therefore, projected changes in both these aspects of flooding are discussed to highlight changing flood hazard at FRIs located in Canada.

\section{Study Region and Data Used}

Canada is the second largest country in the world with a total land mass of $\sim 10$ million square kilometers. It is part of North America and consists of ten provinces and three territories: Yukon (YK), Northwest Territories (NT), Nunavut (NV), British Columbia (BC), Alberta (AB), Saskatchewan (SK), Manitoba (MB), Ontario (ON), Quebec (QB), Newfoundland and Labrador (NL), New Brunswick (NB), Nova Scotia (NS), and Prince Edward Island (PEI), as shown in Figure 1.

The list of 100 most populous cities and their population for the year 2015 is obtained from Statistics Canada (https: / / www.statcan.gc.ca/eng/start). The location of flow regulation infrastructure is obtained from the HYDAT flow database maintained by the Environment and Climate Change Canada (EC Data Explorer 2016). In the HYDAT database, 1072 FRIs have been identified. The distribution of these locations across Canada is shown in Figure 1. 


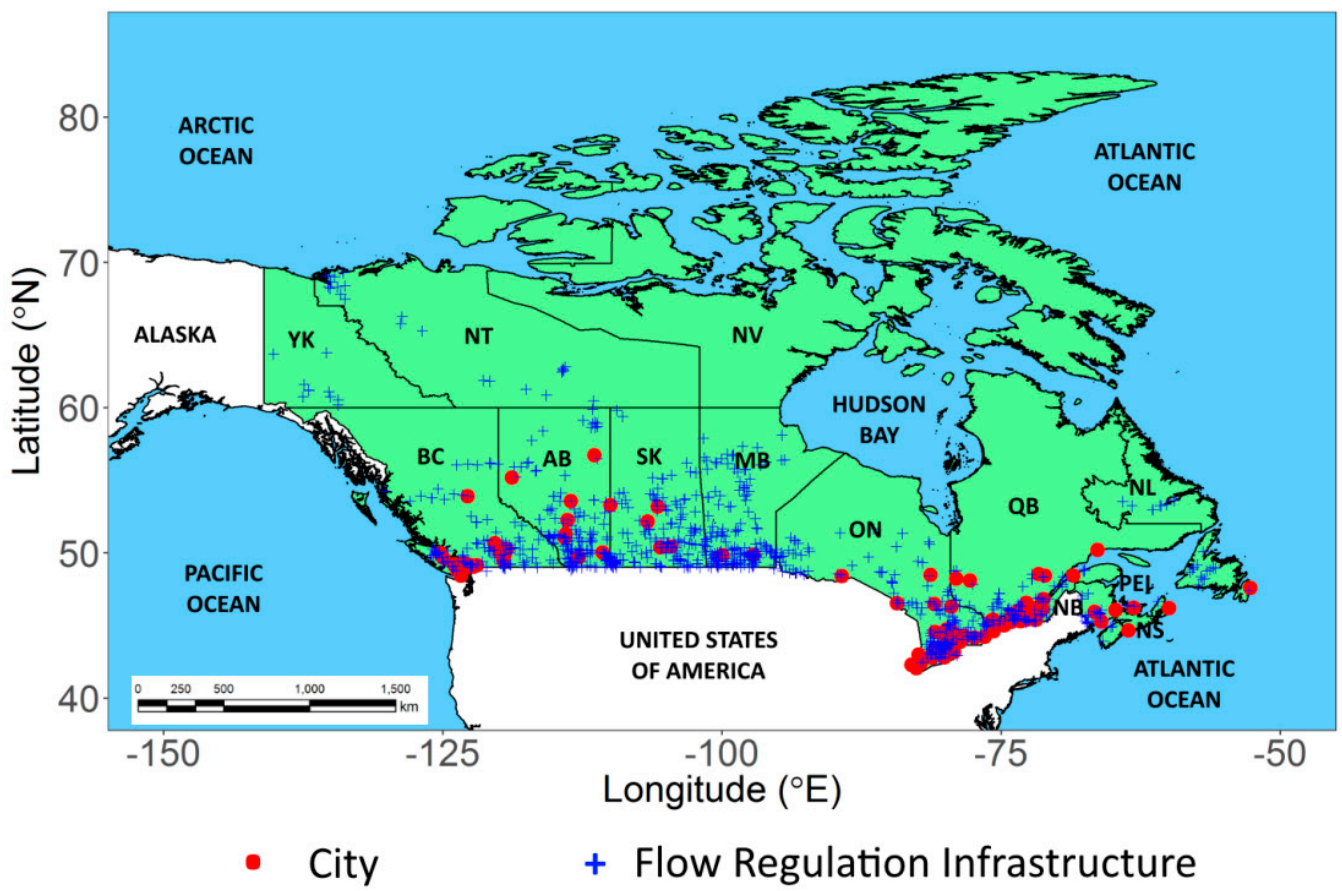

Figure 1. Canada, its administrative boundaries, surrounding countries, and waterbodies. The location of cities and flow regulation locations considered for assessment in this study are shown as red dots and blue crosses respectively.

\section{Results and Discussion}

\subsection{Projected Changes in Flood-Risk in Canadian Cities}

The sign of change in flooding frequencies obtained for 100 most populated cities in Canada obtained by all GCM median and robust GCM median approaches is summarized in Table 1 for 100-year and 250-year return period flooding events. It can be noted that all RCPs and return periods considered, $40-60 \%$ of the cities are projected with future increases in flooding frequencies. Largest numbers of cities with increasing flooding frequencies are projected for RCP 8.5, followed by RCP 6.0, and then followed by RCP 2.6 and RCP 4.5. In addition, the total numbers of cities projected with future increases in flooding frequencies is found to be fractionally larger for 250-year flooding event than 100-year flooding event. Only a small difference in the total numbers of cities projected with future increases in flooding frequencies is obtained between the two methods of aggregation.

Table 1. Sign of change in flooding frequencies projected for 100 most populous Canadian cities.

\begin{tabular}{ccccccc}
\hline \multirow{2}{*}{ RCP } & \multicolumn{3}{c}{ 100-Year } & 250-Year \\
\cline { 2 - 6 } & Decrease & Increase & No Change & Decrease & Increase & No Change \\
\hline \multicolumn{7}{c}{ All GCM Median } \\
RCP 2.6 & 50 & 49 & 1 & 52 & 47 & 1 \\
RCP 4.5 & 55 & 43 & 2 & 51 & 48 & 1 \\
RCP 6.0 & 46 & 53 & 1 & 34 & 65 & 1 \\
RCP 8.5 & 34 & 60 & 6 & 32 & 63 & 5 \\
\hline & 50 & 49 & 1 & 52 & 47 & 1 \\
\hline RCP 2.6 & 56 & 43 & 1 & 51 & 48 & 1 \\
RCP 4.5 & 56 & 53 & 1 & 35 & 64 & 1 \\
RCP 6.0 & 39 & 60 & 1 & 35 & 63 & 1 \\
RCP 8.5 & 39 & Robust GCM median \\
\hline
\end{tabular}


A summary of future projected flooding frequencies for ten most populated Canadian cities obtained from robust GCM median and all GCM median approaches is summarized in Tables 2 and 3 respectively. It can be noted that some of most populous Canadian cities such as Toronto and Montreal are projected with future increases in flooding frequencies whereas other major cities such as Ottawa and Edmonton have been projected with future decreases in the flooding frequencies in the future. Other major cities such as Vancouver, Calgary, and Quebec have been projected with a mix of future increases and decreases in flooding frequencies for different sets of emission scenarios.

Table 2. Projected future return periods of historical 100-year and 250-year return period flood events for 10 most populated Canadian cities obtained from robust GCM median approach. Return periods greater than 200 (500) are only provided categorically in case of 100-year (250-year) return period events. Cases projected with future increases in flooding frequencies are shown in blue whereas cases projected with future decreases in flooding frequencies are shown in orange.

\begin{tabular}{lcccccccc}
\hline \multirow{2}{*}{ City } & \multicolumn{2}{c}{ RCP $\mathbf{2 . 6}$} & \multicolumn{2}{c}{ RCP 4.5 } & \multicolumn{2}{c}{ RCP 6.0 } & \multicolumn{2}{c}{ RCP 8.5 } \\
\cline { 2 - 9 } & $\mathbf{1 0 0 - Y e a r}$ & $\mathbf{2 5 0 - Y e a r}$ & $\mathbf{1 0 0 - Y e a r ~}$ & $\mathbf{2 5 0 - Y e a r}$ & $\mathbf{1 0 0 - Y e a r}$ & $\mathbf{2 5 0 - Y e a r}$ & $\mathbf{1 0 0 - Y e a r}$ & $\mathbf{2 5 0 - Y e a r}$ \\
\hline Toronto & 22 & 37 & 32 & 46 & 32 & 39 & 15 & 22 \\
\hline Montreal & 26 & 38 & 22 & 32 & 18 & 25 & 11 & 16 \\
\hline Vancouver & $\geq 200$ & $\geq 500$ & $\geq 200$ & $\geq 500$ & 20 & 28 & $\geq 200$ & 32 \\
\hline Calgary & 46 & 94 & $\geq 200$ & $\geq 500$ & $\geq 200$ & $\geq 500$ & 49 & 85 \\
\hline Ottawa & $\geq 200$ & $\geq 500$ & $\geq 200$ & $\geq 500$ & $\geq 200$ & $\geq 500$ & $\geq 200$ & $\geq 500$ \\
\hline Edmonton & 104 & 284 & $\geq 200$ & $\geq 500$ & $\geq 200$ & $\geq 500$ & $\geq 200$ & $\geq 500$ \\
\hline Hamilton & 37 & 56 & 151 & 78 & $\geq 200$ & 67 & 27 & 56 \\
\hline Quebec & $\geq 200$ & $\geq 500$ & $\geq 200$ & $\geq 500$ & 27 & 49 & 26 & $\geq 500$ \\
\hline Winnipeg & $\geq 200$ & $\geq 500$ & $\geq 200$ & $\geq 500$ & $\geq 200$ & $\geq 500$ & $\geq 200$ & $\geq 500$ \\
\hline Kitchener & 26 & 47 & $\geq 200$ & 86 & $\geq 200$ & 57 & 29 & 60 \\
\hline
\end{tabular}

Table 3. Projected future return periods of historical 100-year and 250-year return period flood events for 10 most populated Canadian cities obtained from all GCM median approach. Return periods greater than 200 (500) are only provided categorically in case of 100-year (250-year) return period events. Cases projected with future increases in flooding frequencies are shown in blue whereas cases projected with future decreases in flooding frequencies are shown in orange.

\begin{tabular}{ccccccccc}
\hline \multirow{2}{*}{ City } & \multicolumn{2}{c}{ RCP 2.6 } & \multicolumn{2}{c}{ RCP 4.5 } & \multicolumn{2}{c}{ RCP 6.0 } & \multicolumn{2}{c}{ RCP 8.5 } \\
\cline { 2 - 9 } & $\mathbf{1 0 0 - Y e a r ~}$ & $\mathbf{2 5 0 - Y e a r}$ & $\mathbf{1 0 0 - Y e a r}$ & $\mathbf{2 5 0 - Y e a r}$ & $\mathbf{1 0 0 - Y e a r}$ & $\mathbf{2 5 0 - Y e a r}$ & $\mathbf{1 0 0 - Y e a r}$ & $\mathbf{2 5 0 - Y e a r}$ \\
\hline Toronto & 30 & 63 & 39 & 86 & 116 & 227 & 23 & 35 \\
\hline Montreal & 47 & 95 & 24 & 58 & 48 & 178 & 15 & 22 \\
\hline Vancouver & $\geq 200$ & $\geq 500$ & 193 & $\geq 500$ & 34 & 62 & 107 & 157 \\
\hline Calgary & 96 & 199 & 133 & 254 & $\geq 200$ & $\geq 500$ & 87 & 156 \\
\hline Ottawa & $\geq 200$ & $\geq 500$ & $\geq 200$ & $\geq 500$ & $\geq 200$ & $\geq 500$ & $\geq 200$ & $\geq 500$ \\
\hline Edmonton & 104 & 284 & 189 & 476 & $\geq 200$ & $\geq 500$ & $\geq 200$ & $\geq 500$ \\
\hline Hamilton & 79 & 142 & 102 & 223 & 125 & 198 & 76 & 174 \\
\hline Quebec & 175 & $\geq 500$ & $\geq 200$ & $\geq 500$ & 40 & 98 & 72 & 250 \\
\hline Winnipeg & 151 & 416 & 191 & 393 & $\geq 200$ & $\geq 500$ & 121 & 319 \\
\hline Kitchener & 58 & 108 & 103 & 231 & 126 & 188 & 32 & 74 \\
\hline
\end{tabular}

The historical and future flooding frequencies are used to calculate flood-hazard index for different cities. The magnitudes obtained from robust GCM approach are shown in Figure 2. Note that in the figure, flood-hazard indices smaller than -1 are only presented categorically to show the spatial heterogeneity of hazard across the cities. It is found that the cities located in the southern Ontario and western Canada are projected with increases in flood hazard index suggesting future increases in flood hazard in the cities located in these regions. Similar spatial distribution of the hazard magnitudes is also obtained from the results of all GCM median approach (not shown). 


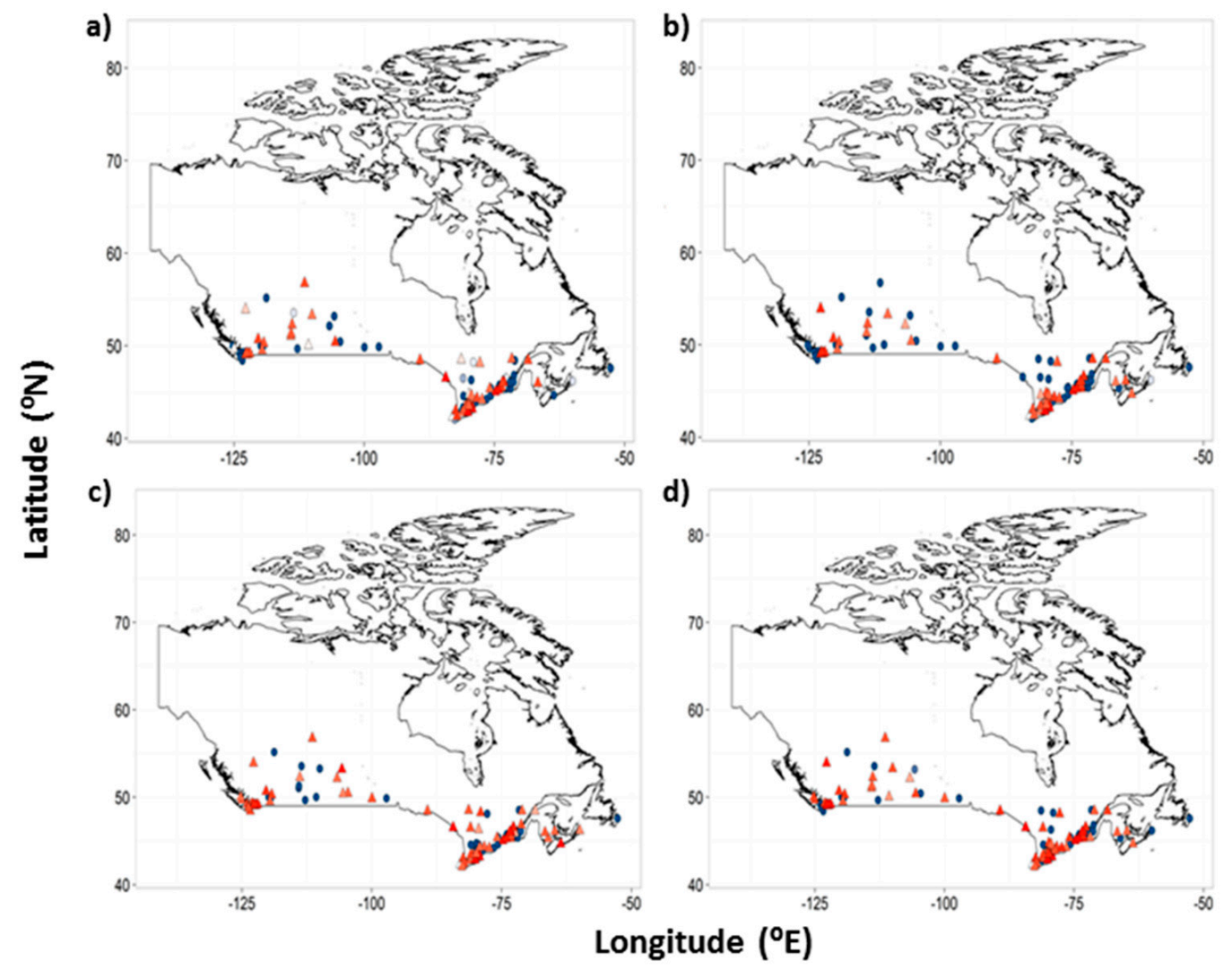

\begin{tabular}{llllll}
\cline { 3 - 4 } & & & & & \\
\end{tabular}

Figure 2. Flood hazard indices for 100 most populated cities in Canada under (a) RCP 2.6; (b) RCP 4.5; (c) RCP 6.0, and (d) RCP 8.5 obtained from robust GCM median approach. Positive values are presented as triangles whereas negative values are presented as dots. The index values below -1 are only shown categorically to show the spatial heterogeneity of the indices.

The calculated flood hazard index is combined with the population exposed to flooding to obtain flood risk index at each city. A scatterplot showing the projected changes in flood risk index values for historical 100-year return period flooding event (for cities projected with an increase in flood risk) and associated flood hazard index, and population, is presented in Figure 3. It can be seen that, as expected, both projected changes in flood hazard index and population exposed to flooding influence the calculated flood risk values at the cities.

Among the cities analyzed, the ten cities that have been projected with largest increases in flood-hazard and flood-risk as obtained from robust GCM median and all GCM median approaches are shown in Tables 4 and 5 respectively. It is noted that some of the cities associated with the highest flood hazard (such as Saint Catharines-Niagara, Nanticoke, Sault Ste. Marie) and risk (such as Saint Catharines-Niagara, Niagara, Toronto) are obtained from the results of both aggregation approaches however some differences in the rankings is also noted. It is particularly noted that the highest numbers of cities featuring in these tables are located in the Ontario province along with some highly populated cities such as Toronto, Montreal, and Saint Catharines-Niagara highlighting large increases in flood-hazard and flood-risk projected for the province. It is also noted that some smaller cities such as Walnut Grove (ON) are also associated with highest flood-hazard magnitudes but lower flood-risks due to smaller population exposed to flooding in these cities. 

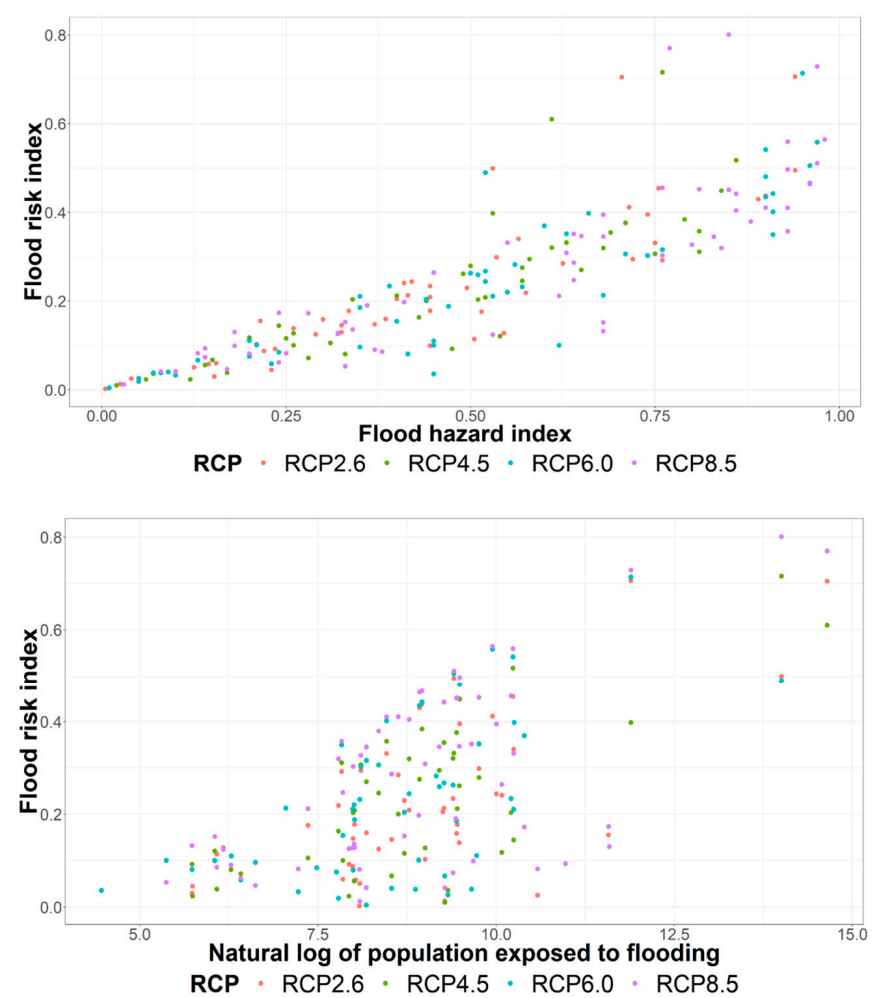

Figure 3. Scatterplot of future projected increases in flood risk with increases in projected flood hazard index, and calculated population exposed to flooding in the Canadian cities. The results are based on all GCM median approach.

\subsection{Flooding Related Impacts on Flow Regulation Infrastructures (FRIs)}

The flooding related impacts of climate change on FRIs are assessed by analyzing future projected changes in flood frequencies and month of extreme flows at their locations. The summary of sign of change in flooding frequencies obtained at the 1072 FRI locations is presented in Table 6 . The spatial distribution of future flooding frequencies of historical 100 year return period floods is presented in Figures 4 and 5 for results obtained from robust GCM median and all GCM median aggregation approaches respectively. Results presented in Table 6 indicate that $40-50 \%$ of the FRIs located in Canada can be subjected to future increases in flooding frequencies under different sets of emission scenarios. From Figures 4 and 5 it can be noted that a vast majority of these FRIs are located in the south-western Ontario, west coast, and northern regions of Canada. A comparison of the results obtained from robust GCM median and all GCM median approaches indicate similar spatial distribution of the projected flooding frequencies among the FRIs but larger absolute magnitudes in the former than the latter. This can be noted both from the results presented in Figures 4 and 5 as well as Table 6 where as a consequence of this, a larger number of FRIs with no projected change in flooding frequencies obtained in the all GCM median case than the robust GCM median case. For instance, a considerable number ( 10\%) of the FRIs are projected with no change in flooding frequencies from all GCM median approach under RCP 8.5 which is considerably higher than the FRIs projected under robust GCM median approach $(\sim 1 \%)$. Between the four RCPs, the largest numbers of FRIs projected with future increases in flooding frequencies are obtained for RCP 6.0, followed by RCP 2.6, RCP 8.5 and RCP 4.5. The FRIs projected with the largest increases in flooding frequencies of historical 100 year return period flooding events from robust GCM median and all GCM median approaches are summarized in Tables 7 and 8 respectively. It can be noted from the results that the FRIs located in the prairies provinces such as Saskatchewan, Manitoba and Alberta, northern provinces such as Nunavut, and Ontario are found to be associated with the highest increases in future flooding frequencies from both aggregation methods. 
Table 4. Ten cities projected with most increases in historical 100-year return period flood-hazard and flood-risk following robust GCM median approach. Information on the province and projected future flood frequency of historical 100-year return period floods in years is also provided within brackets.

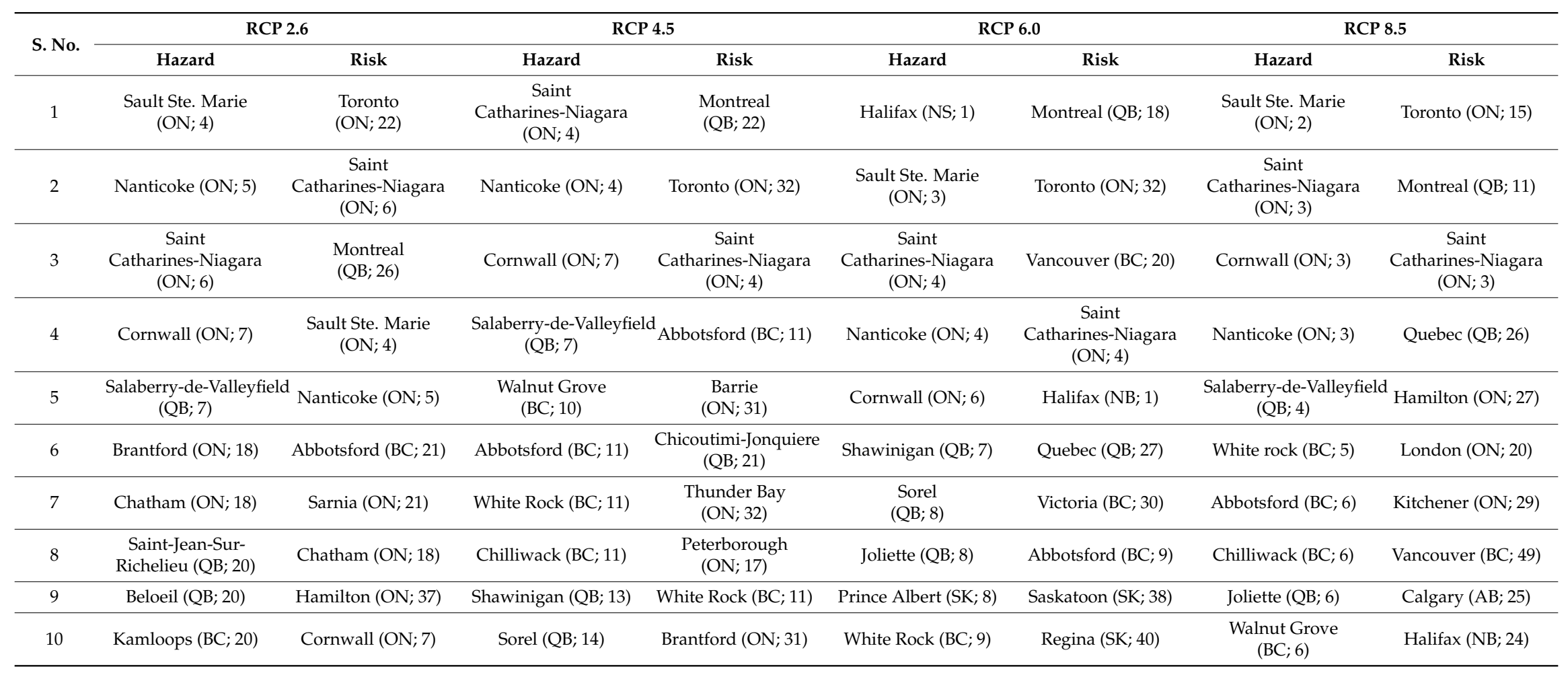


Table 5. Ten cities projected with most increases in flood-hazard and flood-risk of historical 100-year return period floods in future obtained from all GCM median approach. Information on the province and projected future flood frequency magnitudes in years is also provided within brackets.

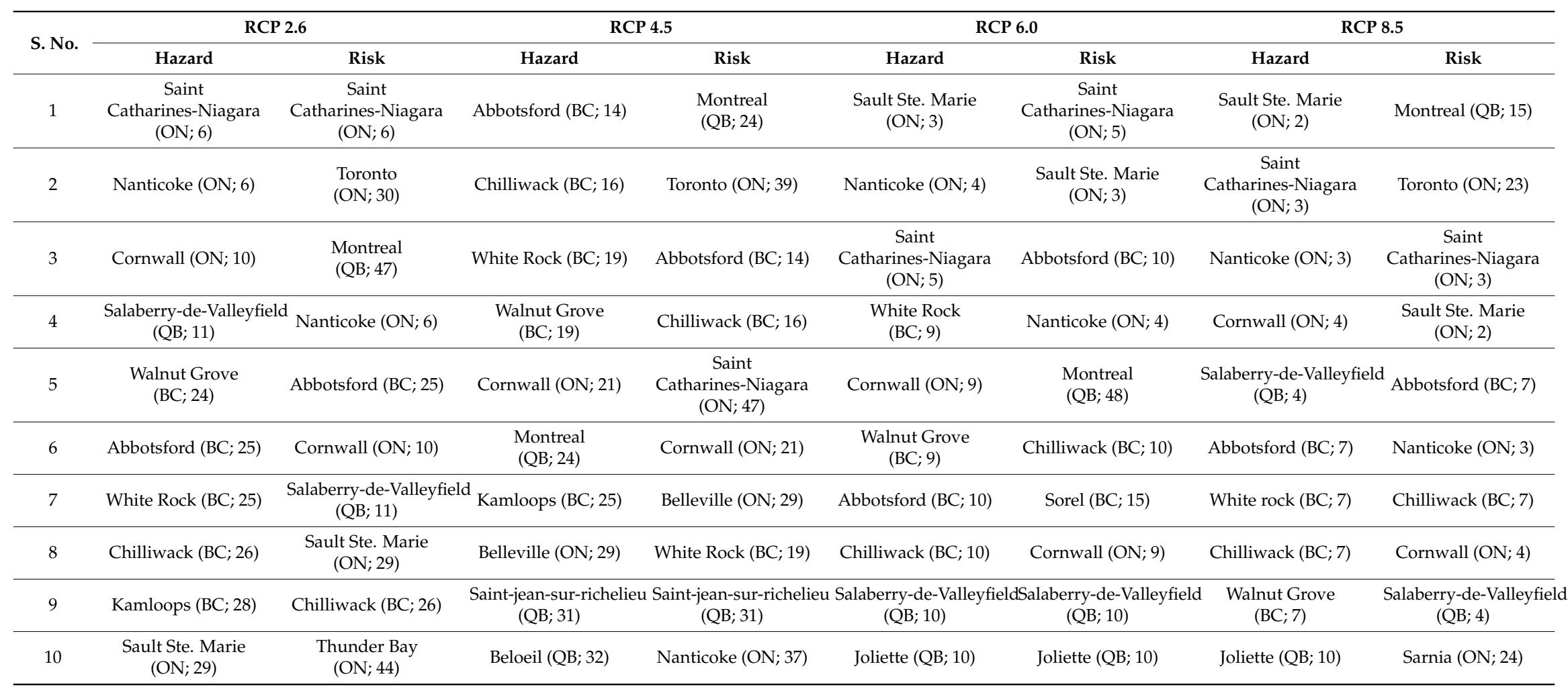


Table 6. Sign of change in flooding frequencies projected for FRIs in Canada.

\begin{tabular}{|c|c|c|c|c|c|c|}
\hline \multirow{2}{*}{ RCP } & \multicolumn{3}{|c|}{ 100-Year } & \multicolumn{3}{|c|}{ 250-Year } \\
\hline & Increase & Decrease & No Change & Increase & Decrease & No Change \\
\hline \multicolumn{7}{|c|}{ All GCM median } \\
\hline RCP 2.6 & 532 & 518 & 22 & 538 & 509 & 25 \\
\hline $\mathrm{RCP} 4.5$ & 639 & 403 & 30 & 623 & 422 & 27 \\
\hline RCP 6.0 & 520 & 523 & 29 & 507 & 544 & 21 \\
\hline RCP 8.5 & 441 & 485 & 146 & 402 & 543 & 127 \\
\hline \multicolumn{7}{|c|}{ Robust GCM median } \\
\hline RCP 2.6 & 543 & 518 & 11 & 553 & 509 & 10 \\
\hline RCP 4.5 & 660 & 403 & 9 & 641 & 422 & 9 \\
\hline RCP 6.0 & 540 & 523 & 9 & 519 & 544 & 9 \\
\hline RCP 8.5 & 578 & 485 & 9 & 520 & 543 & 9 \\
\hline
\end{tabular}
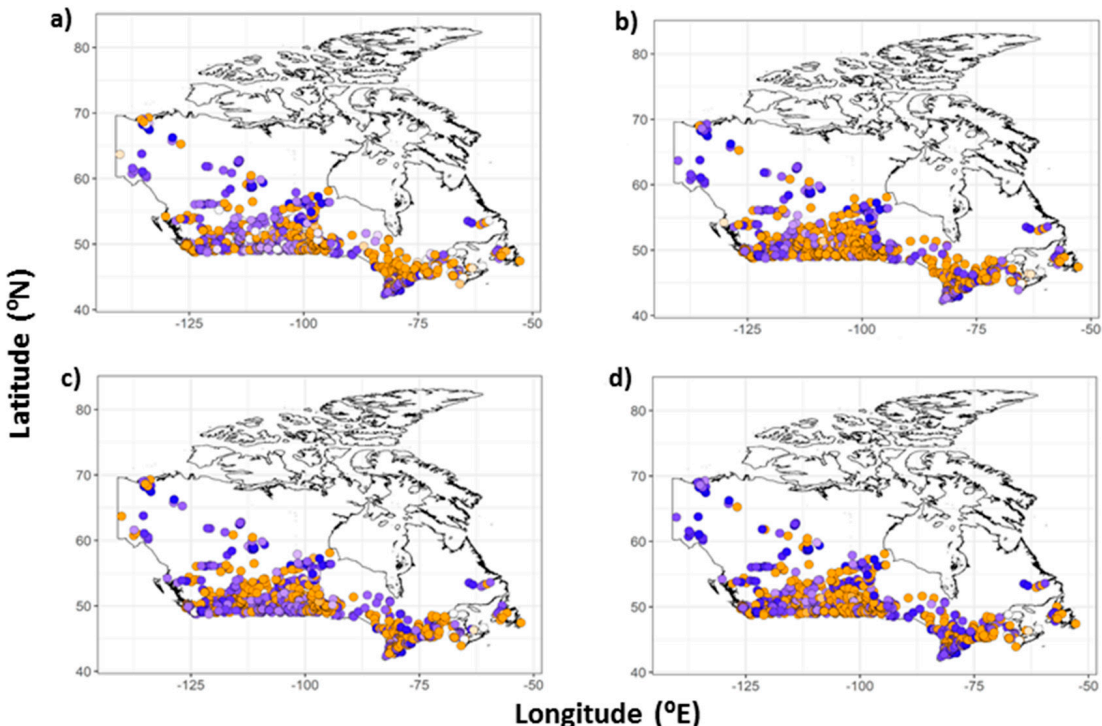

\section{Longitude $\left({ }^{\circ} \mathrm{E}\right)$}

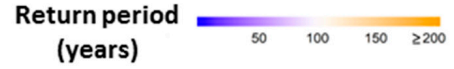

Figure 4. Updated flood frequency of historical 100-year flood magnitudes at FRIs in Canada for (a) RCP 2.6, (b) RCP 4.5, (c) RCP 6.0, and (d) RCP 8.5 obtained from robust GCM median approach.
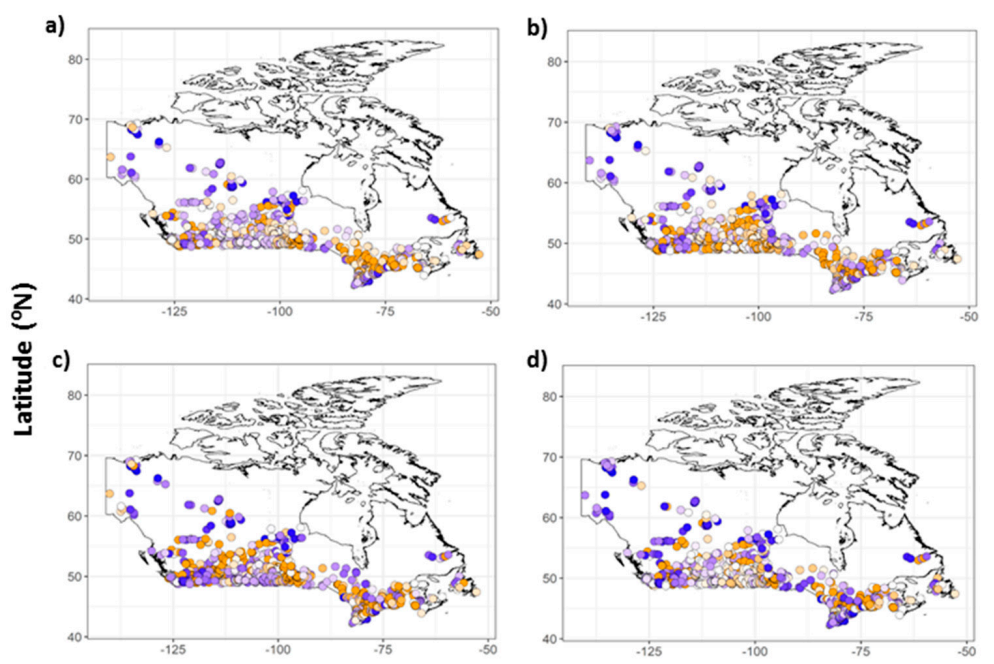

Longitude $\left({ }^{\circ} \mathrm{E}\right)$

Return period (years)

Figure 5. Future projected flooding frequencies of historical 100-year flood magnitudes at FRIs in Canada for (a) RCP 2.6, (b) RCP 4.5, (c) RCP 6.0, and (d) RCP 8.5 obtained from all GCM median. 
Table 7. List of 10 FRIs projected with largest increases in flooding frequencies for historical 100-year return period flooding events from robust GCM median approach. Information on the province and projected future flood frequency magnitudes in years is also provided within brackets.

\begin{tabular}{|c|c|c|c|c|}
\hline S.No. & RCP 2.6 & RCP 4.5 & RCP 6.0 & RCP 8.5 \\
\hline 1 & $\begin{array}{l}\text { Reindeer River Above } \\
\text { Devil Rapids (SK; } 2)\end{array}$ & $\begin{array}{c}\text { Playgreen Lake At } \\
\text { Entrance To East Nelson } \\
\text { River (MB; } 2)\end{array}$ & $\begin{array}{l}\text { Reindeer River Above } \\
\text { Devil Rapids (SK; } 2)\end{array}$ & $\begin{array}{l}\text { St. Marys River At Sault } \\
\text { Ste. Marie (Above) } \\
(\mathrm{ON} ; 2)\end{array}$ \\
\hline 2 & $\begin{array}{l}\text { Churchill River Above Leaf } \\
\text { Rapids (MB; 2) }\end{array}$ & $\begin{array}{c}\text { Sipiwesk Lake At Sipiwesk } \\
\text { Landing } \\
\text { (MB; } 2)\end{array}$ & $\begin{array}{l}\text { Churchill River Above } \\
\text { Leaf Rapid (MB; 2) }\end{array}$ & $\begin{array}{l}\text { St. Marys River At Sault } \\
\text { Ste. Marie (Below) } \\
(\mathrm{ON} ; 2)\end{array}$ \\
\hline 3 & $\begin{array}{l}\text { Churchill River Below } \\
\text { Fidler Lake (MB; 2) }\end{array}$ & $\begin{array}{l}\text { Split Lake At Split Lake } \\
\qquad(\mathrm{MB} ; 2)\end{array}$ & $\begin{array}{l}\text { Churchill River Below } \\
\text { Fidler Lake (MB; 2) }\end{array}$ & $\begin{array}{l}\text { Churchill River Above } \\
\text { Leaf Rapid (MB; 2) }\end{array}$ \\
\hline 4 & $\begin{array}{l}\text { Mackenzie River At Arctic } \\
\text { Red River (NT; 2) }\end{array}$ & $\begin{array}{l}\text { Nelson River At Kettle } \\
\text { Generating Station } \\
\text { (MB; 2) }\end{array}$ & $\begin{array}{l}\text { Peace River Below } \\
\text { Chenal Des Quatre } \\
\text { Fourches }(\mathrm{AB} ; 2)\end{array}$ & $\begin{array}{l}\text { Churchill River Below } \\
\text { Fidler Lake (MB; 2) }\end{array}$ \\
\hline 5 & $\begin{array}{c}\text { Mackenzie River At } \\
\text { Confluence East Channel } \\
(\mathrm{NT} ; 2)\end{array}$ & $\begin{array}{l}\text { Churchill River Below } \\
\text { Fidler Lake (MB; 2) }\end{array}$ & $\begin{array}{l}\text { Riviere Des Rochers } \\
\text { Above Slave River } \\
\text { (AB; 2) }\end{array}$ & $\begin{array}{l}\text { Peace River Below } \\
\text { Chenal Des Quatre } \\
\text { Fourches } \\
(\mathrm{AB} ; 2)\end{array}$ \\
\hline 6 & $\begin{array}{l}\text { Mackenzie River At Fort } \\
\text { Good Hope }(\mathrm{NT} ; 2)\end{array}$ & $\begin{array}{l}\text { Mackenzie River At Arctic } \\
\text { Red River (NT; 2) }\end{array}$ & $\begin{array}{c}\text { Mackenzie River At } \\
\text { Arctic Red River (NT; 2) }\end{array}$ & $\begin{array}{l}\text { Lake Athabasca Near } \\
\text { Crackingstone Point } \\
\text { (SK; 2) }\end{array}$ \\
\hline 7 & $\begin{array}{c}\text { Playgreen Lake At } \\
\text { Entrance To East Nelson } \\
\text { River } \\
(\mathrm{MB} ; 2.5)\end{array}$ & $\begin{array}{c}\text { Mackenzie River At } \\
\text { Confluence East Channel } \\
\text { (NT; 2) }\end{array}$ & $\begin{array}{c}\text { Mackenzie River At } \\
\text { Confluence East Channel } \\
(\text { NT; } 2)\end{array}$ & $\begin{array}{l}\text { Riviere Des Rochers } \\
\text { Above Slave River } \\
\qquad(\mathrm{AB} ; 2)\end{array}$ \\
\hline 8 & $\begin{array}{l}\text { Sipiwesk Lake At Sipiwesk } \\
\text { Landing } \\
(\mathrm{MB} ; 2.5)\end{array}$ & $\begin{array}{l}\text { Mackenzie River At Fort } \\
\text { Good Hope (NT; 2) }\end{array}$ & $\begin{array}{l}\text { Mackenzie River At Fort } \\
\text { Good Hope (NT; 2) }\end{array}$ & $\begin{array}{c}\text { Riviere Des Rochers East } \\
\text { Of Little Rapids } \\
(\mathrm{AB} ; 2)\end{array}$ \\
\hline 9 & $\begin{array}{c}\text { Mackenzie River (Peel } \\
\text { Channel) Above Aklavik } \\
\text { (NT; 2.5) }\end{array}$ & $\begin{array}{c}\text { Mackenzie River (Peel } \\
\text { Channel) Above Aklavik } \\
\text { (NT;2) }\end{array}$ & $\begin{array}{c}\text { Mackenzie River (Peel } \\
\text { Channel) Above Aklavik } \\
\text { (NT; 2) }\end{array}$ & $\begin{array}{c}\text { Riviere Des Rochers West } \\
\text { Of Little Rapids } \\
(\mathrm{AB} ; 2)\end{array}$ \\
\hline 10 & $\begin{array}{c}\text { Cedar Lake Near Oleson } \\
\text { Point }(\mathrm{MB} ; 3)\end{array}$ & $\begin{array}{l}\text { Churchill River Above Leaf } \\
\text { Rapids (MB; 2.5) }\end{array}$ & $\begin{array}{l}\text { St. Marys River At Sault } \\
\text { Ste. Marie } \\
\text { (Above) }(\mathrm{ON} ; 3)\end{array}$ & $\begin{array}{c}\text { Mackenzie River At } \\
\text { Arctic Red River (NT; } 2)\end{array}$ \\
\hline
\end{tabular}

Finally, projected changes in the flood timings across the FRIs are also assessed. The results are summarized in Table 9 and Figures 6 and 7. In Table 9, the total numbers of FRIs that are projected with change or no-change in flood timing are summarized along with the FRIs where uncertain flood timings are obtained for either historical or future time-periods. From the results obtained from all GCM median approach, more numbers of FRIs are projected with no-change in flood timing than FRIs projected with a change in flood timing for RCP 2.6 and RCP 4.5 whereas the opposite is noted in case of more severe emission scenarios i.e., RCP 6.0 and RCP 8.5. This suggests that a larger number of FRIs can be expected to experience changes in flood timings under more severe emission scenarios than the low and moderate ones. Figure 6 suggests that a large number of FRIs projected with changes in flood timings are located in southern Ontario, southern prairies, and along the west coast of Canada whereas FRIs projected with no change in flood timings are distributed along the east coast, northern Ontario, and northern prairies regions of Canada. 
Table 8. List of 10 FRIs projected with largest increases in flooding frequencies for historical 100-year return period flooding events from all GCM median approach. Information on the province and projected future flood frequency magnitudes in years is also provided within brackets.

\begin{tabular}{|c|c|c|c|c|}
\hline S.No & RCP 2.6 & RCP 4.5 & RCP 6.0 & RCP 8.5 \\
\hline 1 & $\begin{array}{l}\text { Mackenzie River At Fort } \\
\text { Good Hope (NT; } 2)\end{array}$ & $\begin{array}{l}\text { Churchill River Below } \\
\text { Fidler Lake (MB; 2) }\end{array}$ & $\begin{array}{l}\text { Reindeer River Above } \\
\text { Devil Rapids (SK; } 2)\end{array}$ & $\begin{array}{l}\text { St. Marys River At Sault } \\
\text { Ste. Marie (Above) } \\
\text { (ON; } 2)\end{array}$ \\
\hline 2 & $\begin{array}{l}\text { Churchill River Above Leaf } \\
\text { Rapids (MB; 2.5) }\end{array}$ & $\begin{array}{l}\text { Mackenzie River At Arctic } \\
\text { Red River (NT; 2) }\end{array}$ & $\begin{array}{l}\text { Churchill River Above } \\
\text { Leaf Rapids (MB; 2) }\end{array}$ & $\begin{array}{l}\text { St. Marys River At Sault } \\
\text { Ste. Marie (Below) } \\
(\mathrm{ON} ; 2)\end{array}$ \\
\hline 3 & $\begin{array}{l}\text { Churchill River Below } \\
\text { Fidler Lake (MB; } 2.5)\end{array}$ & $\begin{array}{c}\text { Mackenzie River At } \\
\text { Confluence East Channel } \\
(\mathrm{NT} ; 2)\end{array}$ & $\begin{array}{l}\text { Peace River Below } \\
\text { Chenal Des Quatre } \\
\text { Fourches }(\mathrm{AB} ; 2)\end{array}$ & $\begin{array}{l}\text { Churchill River Above } \\
\text { Leaf Rapids (MB; 2) }\end{array}$ \\
\hline 4 & $\begin{array}{c}\text { Playgreen Lake At } \\
\text { Entrance To East Nelson } \\
\text { River (MB; } 3)\end{array}$ & $\begin{array}{l}\text { Mackenzie River At Fort } \\
\text { Good Hope (NT; 2) }\end{array}$ & $\begin{array}{c}\text { Riviere Des Rochers } \\
\text { Above Slave River }(\mathrm{AB} ; 2)\end{array}$ & $\begin{array}{l}\text { Churchill River Below } \\
\text { Fidler Lake (MB; 2) }\end{array}$ \\
\hline 5 & $\begin{array}{l}\text { Peace River Below Chenal } \\
\text { Des Quatre Fourches (AB; } \\
\text { 3) }\end{array}$ & $\begin{array}{c}\text { Mackenzie River (Peel } \\
\text { Channel) Above Aklavik } \\
\text { (NT; 2) }\end{array}$ & $\begin{array}{c}\text { Mackenzie River At } \\
\text { Arctic Red River (NT; 2) }\end{array}$ & $\begin{array}{l}\text { Peace River Below } \\
\text { Chenal Des Quatre } \\
\text { Fourches }(\mathrm{AB} ; 2)\end{array}$ \\
\hline 6 & $\begin{array}{l}\text { Riviere Des Rochers Above } \\
\text { Slave River (AB; } 3)\end{array}$ & $\begin{array}{l}\text { Reindeer River Above } \\
\text { Devil Rapids (SK; } 3 \text { ) }\end{array}$ & $\begin{array}{c}\text { Mackenzie River At } \\
\text { Confluence East Channel } \\
(\mathrm{NT} ; 2)\end{array}$ & $\begin{array}{c}\text { Riviere Des Rochers } \\
\text { Above Slave River }(\mathrm{AB} ; 2)\end{array}$ \\
\hline 7 & $\begin{array}{l}\text { Mackenzie River At Arctic } \\
\text { Red River (NT; 3) }\end{array}$ & $\begin{array}{c}\text { Churchill River Above Leaf } \\
\text { Rapids (MB; 3) }\end{array}$ & $\begin{array}{l}\text { Mackenzie River At Fort } \\
\text { Good Hope (NT; 2) }\end{array}$ & $\begin{array}{c}\text { Mackenzie River At } \\
\text { Arctic Red River (NT; } 2)\end{array}$ \\
\hline 8 & $\begin{array}{c}\text { Mackenzie River At } \\
\text { Confluence East Channel } \\
\text { (NT;3) }\end{array}$ & $\begin{array}{c}\text { Peace River Below Chenal } \\
\text { Des Quatre Fourches } \\
(\mathrm{AB} ; 3)\end{array}$ & $\begin{array}{l}\text { Mackenzie River (Peel } \\
\text { Channel) Above Aklavik } \\
(\mathrm{NT} ; 2)\end{array}$ & $\begin{array}{c}\text { Mackenzie River At } \\
\text { Confluence East Channel } \\
(\mathrm{NT} ; 2)\end{array}$ \\
\hline 9 & $\begin{array}{c}\text { Mackenzie River (Peel } \\
\text { Channel) Above Aklavik } \\
\text { (NT;3) }\end{array}$ & $\begin{array}{l}\text { Riviere Des Rochers Above } \\
\text { Slave River }(\mathrm{AB} ; 3)\end{array}$ & $\begin{array}{l}\text { St. Marys River At Sault } \\
\text { Ste. Marie (Above) } \\
(\mathrm{ON} ; 3)\end{array}$ & $\begin{array}{l}\text { Mackenzie River At Fort } \\
\text { Good Hope (NT; } 2)\end{array}$ \\
\hline 10 & $\begin{array}{l}\text { Sipiwesk Lake At Sipiwesk } \\
\text { Landing } \\
\text { (MB; } 3.5)\end{array}$ & $\begin{array}{c}\text { Lake Athabasca Near } \\
\text { Crackingstone Point (SK; 4) }\end{array}$ & $\begin{array}{l}\text { St. Marys River At Sault } \\
\text { Ste. Marie (Below) } \\
(\mathrm{ON} ; 3)\end{array}$ & $\begin{array}{l}\text { Mackenzie River (Peel } \\
\text { Channel) Above Aklavik } \\
\text { (NT; 2) }\end{array}$ \\
\hline
\end{tabular}

Table 9. Total numbers of FRIs (out of 1072) projected with a change in flood timing in Canada.

\begin{tabular}{ccccccc}
\hline \multirow{2}{*}{ RCP } & \multicolumn{3}{c}{ All GCM Median } & \multicolumn{3}{c}{ Robust GCM Median } \\
\cline { 2 - 7 } & Change & No Change & Uncertain & Change & No Change & Uncertain \\
\hline RCP 2.6 & 417 & 655 & 0 & 126 & 352 & 594 \\
RCP 4.5 & 510 & 562 & 0 & 124 & 167 & 781 \\
RCP 6.0 & 638 & 434 & 0 & 209 & 178 & 685 \\
RCP 8.5 & 676 & 396 & 0 & 115 & 83 & 874 \\
\hline
\end{tabular}

Flood timing results obtained from robust GCM median approach and shown in Table 9 suggest that a large number of FRIs are associated with uncertain flood timings. Similar to the results from all GCM median approach, the total numbers of FRIs projected with change in flood timings are smaller than FRIs projected with no-change for RCP 2.6 and RCP 4.5 whereas they are larger for RCP 6.0 and RCP 8.5. From Figure 7 it can also be noted that FRIs located in the western prairies regions, British Columbia province, and east coast regions are associated with large uncertainties in simulated flood timing. On the other hand, FRIs located in eastern prairies regions, southern Ontario, and northern regions are reliably projected with earlier shifts in flood timing ranging 1-2 months. 

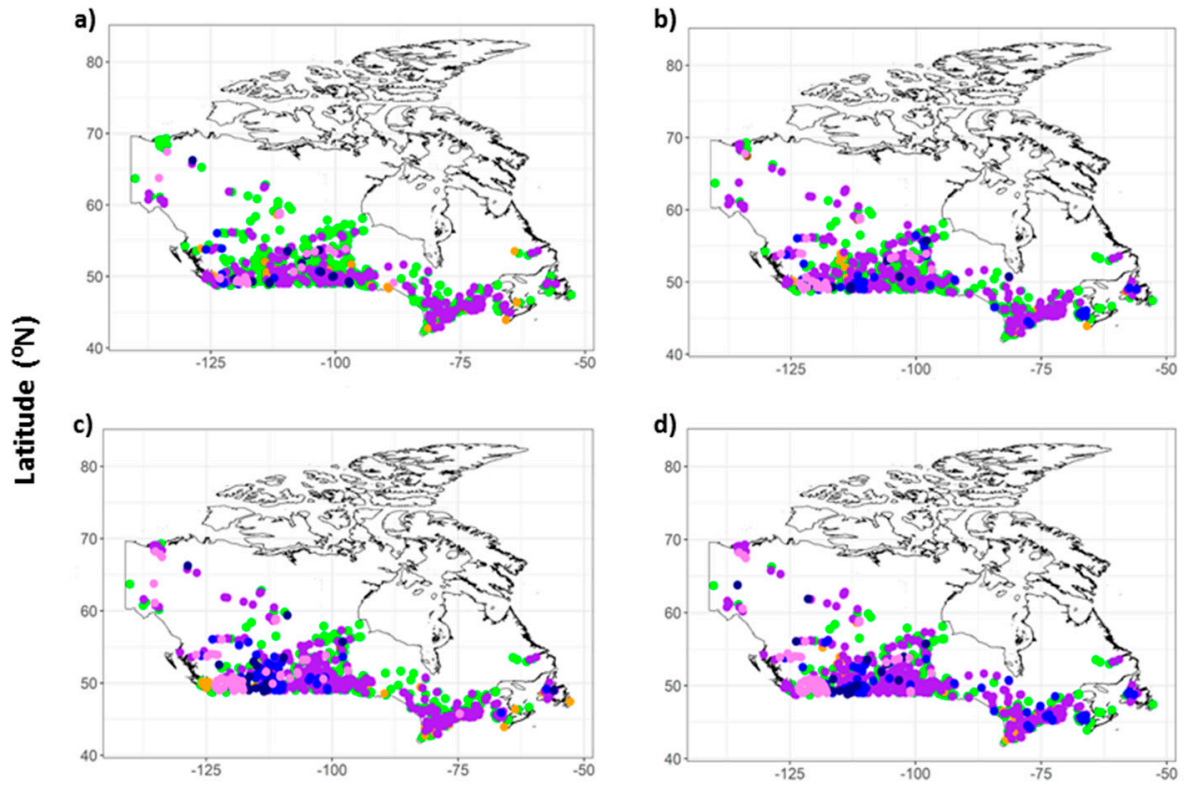

Longitude $\left({ }^{\circ} \mathrm{E}\right)$

Figure 6. The change in flood timing obtained from all GCM median approach at FRIs under (a) RCP 2.6, (b) RCP 4.5, (c) RCP 6.0, and (d) RCP 8.5. FRIs projected with no change in flood timing are shown in green. FRIs projected with earlier occurrences of floods are shown in shades of blue (purple for 1 month shift, blue for 2 months shift, and dark blue for 3 month shift). FRIs projected with later occurrences of floods are shown in shades of orange (1-3 month shifts shown in light to dark orange). Finally, FRIs where 4 or more months of changes (in either direction) are projected, are shown in pink.
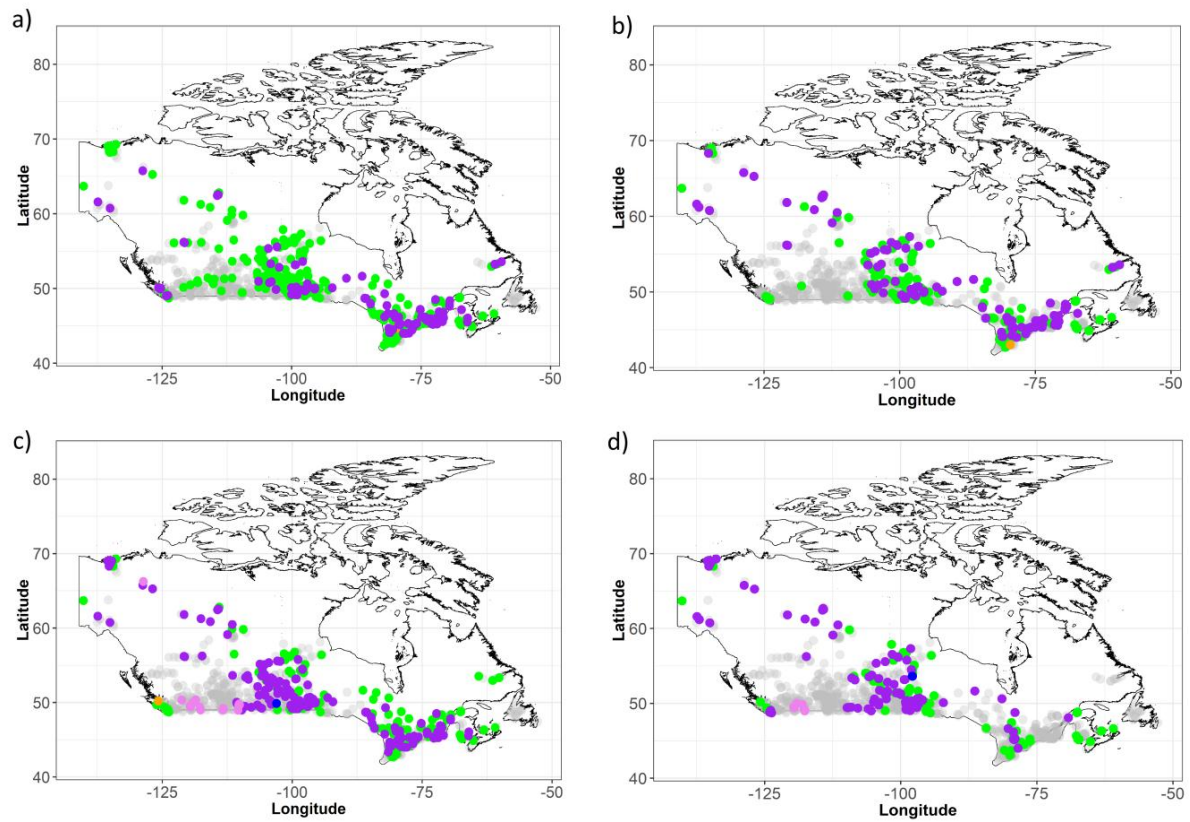

Figure 7. The change in flood timing obtained from robust GCM median approach at FRIs under (a) RCP 2.6, (b) RCP 4.5, (c) RCP 6.0, and (d) RCP 8.5. FRIs projected with no change in flood timing are shown in green. FRIs projected with earlier occurrences of floods are shown in shades of blue (purple for 1 month shift, blue for 2 months shift, and dark blue for 3 month shift). FRIs projected with later occurrences of floods are shown in shades of orange (1-3 month shifts shown in light to dark orange). FRIs where 4 or more months of changes (in either direction) are projected, are shown in pink. Finally, FRIs projected with uncertain flood timing in either historical or future timelines are shown in grey. 


\section{Conclusions}

This study discussed the flooding related consequences of climate change on 100 most populous Canadian cities and Flow Regulation Infrastructure (FRIs) located in Canada. The aggregated results of future projected changes in flooding frequencies of historical 100 and 250 year flooding events, and changes in flood timing generated discussed in Gaur et al. [16] are used as the basis for the discussion presented in this study. Two different approaches were used to aggregate the projected changes: (1) all GCM median approach where changes projected by all GCMs (for a particular RCP) were taken into consideration and their median is calculated as the aggregated value, and (2) robust GCM median approach where changes projected by robust GCMs were considered for aggregation. More details on the procedure used to calculate the aggregated results can be obtained from Gaur et al. [16].

The projected changes from both aggregation approaches are used to assess changes in future flooding frequencies at the cities, and calculate flood hazard indices and flood risk indices to evaluate flooding related consequences of climate change on the cities. Overall, it is obtained that $40-60 \%$ of the cities are projected with increasing flooding frequencies in the future. The number of cities projected with increasing flooding frequencies, increased flood hazard index, and increased flood risk was found to be greatest under the more intense emission scenarios: RCP 6.0 and RCP 8.5 than the conservative scenarios: RCP 2.6 and RCP 4.5. In terms of chosen hazard and risk indices, it is especially noted that many cities located in southern Ontario such as Sault Ste. Marie, Nanticoke, Cornwall etc. are associated with very high flood hazard whereas other highly populated cities such as Toronto, Montreal, and Saint Catharines-Niagara are associated with the highest flood risk. Some heavily populated cities such as Ottawa and Edmonton have also been projected with future increases in flooding frequencies, decreasing flood hazard and flood risk. Large uncertainty in the sign of change as contributed by differences in RCPs is also evident in the results for some cities such as Vancouver, Quebec etc.

The flooding related consequences of climate change on FRIs are evaluated in terms of the projected changes in flooding frequencies and flood timing at their locations. Results indicate that overall 40-50\% FRIs especially those located in the south-western Ontario, west coast, and northern regions of Canada can experience future increases in flooding frequencies as a consequence of climate change. The FRIs projected to experience the largest increases in flooding frequencies are found to be located in the prairies provinces such as Saskatchewan, Manitoba and Alberta, northern provinces such as Nunavut, and Ontario. In terms of flood timing, the projected results were found to differ considerably between the two aggregation approaches where the results from robust GCM median approach allocated uncertain flood timing in a larger number of FRIs. However from both the aggregation approaches, a larger number of FRIs especially those located in the southern Ontario, southern prairies, and along the western coast of Canada were found to be projected with a change in flood timing under more extreme emission scenarios: RCP 6.0 and RCP 8.5 than low and moderate emission scenarios: RCP 2.6 and RCP 4.5.

It is also worth pointing out some of the limitations and future work of this study. The results discussed in this study are based on the aggregated projections from multiple GCMs and no attempt has been made to evaluate the reliability of runoff projections made by them. However, in line with the recommendations made in previous studies (such as Knutti et al. [39]), a very large ensemble of future runoff projections have been used for analysis so that the recommendations made are robust given the limitations and uncertainty in making future projections of runoff. The estimation of flood quantiles for historical and projected future time-periods has been made considering that flooding behavior is stationary within the two time-periods however extreme value distribution methods accounting for non-stationarity exist [40] and can be used in future studies to further validate the findings of this study. Furthermore, this study only evaluates hazards and risks originating from riverine floods. Other categories of floods originating in the coastal areas due to tidal effects and sea-level rise, short duration extreme precipitation, ice-jams, and tsunamis have not been considered. Concurrency of some of these flood generating mechanisms have the potential to generate much larger flood hazard than that 
discussed in this study. Nevertheless, the results discussed in this paper provide novel information that will help water resource managers and policy makers to more effectively manage Canadian cities and water resource management infrastructure in Canada.

Author Contributions: A.G. (Ayushi Gaur) conceptualized the research, performed the formal analysis, and wrote the first draft of the paper. A.G. (Abhishek Gaur), D.Y., and S.P.S. provided feedback on the research approach, and reviewed and edited the first draft of the paper. All authors revised the paper and agreed on the final version of the paper.

Funding: Funding for this research came from Chaucer Syndicates (London, UK) and the Natural Sciences and Engineering Research Council of Canada (NSERC).

Acknowledgments: Authors acknowledge the financial support of Chaucer Syndicates (London, UK) and Natural Sciences and Engineering Research Council of Canada (NSERC) through the collaborative research grant awarded to the last author.

Conflicts of Interest: The authors declare no conflict of interest.

\section{References}

1. IPCC. Summary for Policymakers. In: Climate Change 2013: The Physical Science Basis. In Contribution of Working Group I to the Fifth Assessment Report of the Intergovernmental Panel on Climate Change; Stocker, T.F., Qin, D., Plattner, G.-K., Tignor, M., Allen, S.K., Boschung, J., Nauels, A., Xia, Y., Bex, V., Midgley, P.M., Eds.; Cambridge University Press: Cambridge, UK; New York, NY, USA, 2013.

2. IPCC. Managing the Risks of Extreme Events and Disasters to Advance Climate Change Adaptation. In A Special Report of Working Groups I and II of the Intergovernmental Panel on Climate Change; Field, C.B., Barros, V., Stocker, T.F., Qin, D., Dokken, D.J., Ebi, K.L., Mastrandrea, M.D., Mach, K.J., Plattner, G.K., Allen, S.K., et al., Eds.; Cambridge University Press: Cambridge, UK; New York, NY, USA, 2012; p. 582.

3. Watt, W.E.; Lathem, K.W.; Neill, C.R.; Richards, T.L.; Rousselle, J. Hydrology of Floods in Canada: A Guide to Planning and Design; National Research Council of Canada: Ottawa, ON, Canada, 1989.

4. Andrews, J. Flooding: Canada Water Year Book; Ministry of Supply and Services: Ottawa, ON, USA, 1993.

5. Burn, D.H.; Elnur, M.A. Detection of hydrological trends and variability. J. Hydrol. 2002, 255, 107-122. [CrossRef]

6. Burn, D.H.; Fan, L.; Bell, G. Identification and quantification of streamflow trends on the Canadian Prairies. Hydrol. Sci. 2008, 53, 538-549. [CrossRef]

7. Déry, S.J.; Stahl, K.; Moore, R.D.; Whitfield, P.H.; Menounos, B.; Burford, J.E. Detection of runoff timing changes in pluvial, nival and glacial rivers of western Canada. Water Resour. Res. 2009, 45, W04426. [CrossRef]

8. Burn, D.H.; Sharif, M.; Zhang, K. Detection of trends in hydrological extremes for Canadian watersheds. Hydrol. Process. 2010, 24, 1781-1790. [CrossRef]

9. Sandink, D. Urban Flooding in Canada; Institute for Catastrophic Loss Reduction: London, ON, Canada, 2013; Volume 52, pp. 1-94.

10. Gaur, A.; Simonovic, S.P. Projected Changes in the Dynamics of Flood Hazard in the Grand River Basin, Canada. Br. J. Environ. Clim. Chang. 2015, 5, 37-51. [CrossRef]

11. Fiorentino, M.; Gioia, A.; Iacobellis, V.; Manfreda, S. Regional analysis of runoff thresholds behaviour in Southern Italy based on theoretically derived distributions. Adv. Geosci. 2011, 26, 139-144. [CrossRef]

12. Gioia, A.; Manfreda, S.; Iacobellis, V.; Fiorentino, M. Performance of a theoretical model for the description of water balance and runoff dynamics in Southern Italy. J. Hydrol. Eng. 2014, 19, 1113-1123. [CrossRef]

13. Devkota, L.P.; Gyawali, D.R. Impacts of climate change on hydrological regime and water resources management of the Koshi River Basin, Nepal. J. Hydrol. Reg. Stud. 2015, 4B, 502-515. [CrossRef]

14. Qin, X.S.; Lu, Y. Study of Climate Change Impact on Flood Frequencies: A Combined Weather Generator and Hydrological Modeling Approach. J. Hydrometeorol. 2014, 15, 1205-1219. [CrossRef]

15. Das, S.; Millington, N.; Simonovic, S.P. Distribution choice for the assessment of design rainfall for the city of London (Ontario, Canada) under climate change. Can. J. Civ. Eng. 2012, 40, 121-129. [CrossRef]

16. Gaur, A.; Gaur, A.; Simonovic, S.P. Future Changes in Flood Hazards across Canada under a Changing Climate. Water 2018, 10, 1441. [CrossRef] 
17. Ranger, N.; Hallegatte, S.; Bhattacharya, S.; Bachu, M.; Priya, S.; Dhore, K.; Rafique, F.; Mathur, P.; Naville, N.; Henriet, F.; et al. An assessment of the potential impact of climate change on flood risk in Mumbai. Clim. Chang. 2011, 104, 139-167. [CrossRef]

18. Kundzewicz, Z.; Kanae, S.; Seneviratne, S.; Handmer, J.; Nicholls, N.; Peduzzi, P.; Mechler, R.; Bouwer, L.; Arnell, N.; Mach, K.; et al. Flood risk and climate change: Global and regional perspectives [le risque d'inondation et les perspectives de changement climatique mondial et regional]. Hydrol. Sci. J. 2014, 59, 1-28. [CrossRef]

19. Pappenberger, F.; Dutra, E.; Wetterhall, F.; Cloke, H.L. Deriving global flood hazard maps of fluvial floods through a physical model cascade. Hydrol. Earth Syst. Sci. 2012, 16, 4143-4156. [CrossRef]

20. Hirabayashi, Y.; Mahendran, R.; Koirala, S.; Konoshima, L.; Yamazaki, D.; Watanabe, S.; Kanae, S. Global flood risk under climate change. Nat. Clim. Chang. 2013, 3, 816-821. [CrossRef]

21. Winsemius, H.C.; Van Beek, L.P.H.; Jongman, B.; Ward, P.J.; Bouwman, A. A framework for global river flood risk assessments. Hydrol. Earth Syst. Sci. 2013, 17, 1871-1892. [CrossRef]

22. Yamazaki, D.; Lee, H.; Alsdorf, E.; Dutra, E.; Kim, H.; Kanae, S.; Oki, T. Analysis of the water level dynamics simulated by a global river model: A case study in the Amazon River. Water Resour. Res. 2012, 48, W09508. [CrossRef]

23. Dankers, R.; Feyen, L. Climate change impact on flood hazard in Europe: An assessment based on high resolution climate simulations. J. Geophys. Res. 2008, 113, D19105. [CrossRef]

24. Yamazaki, D.; Kanae, S.; Kim, H.; Oki, T. A physically based description of floodplain inundation dynamics in a global river routing model. Water Resour. Res. 2011, 47, 1-21. [CrossRef]

25. Jongman, B.; Ward, P.J.; Aerts, J.C.J.H. Global exposure to river and coastal flooding: Long term trends and changes. Glob. Environ. Chang. 2012, 22, 823-835. [CrossRef]

26. Peduzzi, P.; Dao, H.; Herold, C.; Mouton, F. Assessing global exposure and vulnerability towards natural hazards: The Disaster Risk Index. Nat. Hazards Earth Syst. Sci. 2009, 9, 1149-1159. [CrossRef]

27. de Moel, H.; Aerts, J.C.J.H.; Koomen, E. Development of flood exposure in the Netherlands during the 20th and 21st century. Glob. Environ. Chang. 2011, 21, 620-627. [CrossRef]

28. Kleinen, T.; Petschel-Held, G. Integrated assessment of changes in flooding probabilities due to climate change. Clim. Chang. 2007, 81, 283-312. [CrossRef]

29. Feyen, L.; Barredo, J.I.; Dankers, R. Implications of global warming and urban land use change on flooding in Europe. In Water and Urban Development Paradigms-Towards an Integration of Engineering, Design and Management Approaches; Feyen, J., Shannon, K., Neville, M., Eds.; CRC Press: London, UK, 2009; pp. 217-225.

30. Feyen, L.; Dankers, R.; Bódis, K.; Salamon, P.; Barredo, J.I. Fluvial flood risk in Europe in present and future climates. Clim. Chang. 2012, 112, 47-62. [CrossRef]

31. Van Vuuren, D.P. The representative concentration pathways: An overview. Clim. Chang. 2011, 109, 5-31. [CrossRef]

32. Yamazaki, D.; Oki, T.; Kanae, S. Deriving a global river network map and its sub-grid topographic characteristics from a fine-resolution flow direction map. Hydrol. Earth Syst. Sci. 2009, 13, 2241-2251. [CrossRef]

33. Ikeuchi, H.; Hirabayashi, Y.; Yamazaki, D.; Kiguchi, M.; Koirala, S.; Nagano, T.; Kotera, A.; Kanae, S. Modeling complex flow dynamics of fluvial floods exacerbated by sea level rise in the Ganges-Brahmaputra-Meghna delta. Environ. Res. Lett. 2015, 10, 124011. [CrossRef]

34. Hu, X.; Hall, J.W.; Shi, P.; Lim, W.H. The spatial exposure of the Chinese infrastructure system to flooding and drought hazards. Nat. Hazards 2016, 80, 1083-1118. [CrossRef]

35. Mateo, C.M.; Hanasaki, N.; Komori, D.; Tanaka, K.; Kiguchi, M.; Champathong, M.; Sukhapunnaphan, T.; Yamazaki, D.; Oki, T. Assessing the impacts of reservoir operation to floodplain inundation by combining hydrological, reservoir management, and hydrodynamic models. Water Resour. Res. 2014, 50, 7245-7266. [CrossRef]

36. Koirala, S.; Hirabayashi, Y.; Mahendran, R.; Kanae, S. Global assessment of agreement among streamflow projections using CMIP5 model outputs. Environ. Res. Lett. 2014, 9, 064017. [CrossRef]

37. Takata, K.; Emori, S.; Watanabe, T. Development of the minimal advanced treatments of surface interaction and runoff. Glob. Planet. Chang. 2003, 38, 209-222. [CrossRef]

38. Kim, H.; Yeh, P.; Oki, T.; Kanae, S. Role of rivers in the seasonal variations of terrestrial water storage over global basins. Geophys. Res. Lett. 2009, 36, L17402. [CrossRef] 
39. Knutti, R.; Furrer, R.; Tebaldi, C.; Cermak, J.; Meehl, G.A. Challenges in Combining Projections from Multiple Climate Models. J. Clim. 2010, 23, 2739-2758. [CrossRef]

40. Salas, J.D.; Obeysekera. Revisiting the Concepts of Return Period and Risk for Nonstationary Hydrologic Extreme Events. J. Hydrol. Eng. 2014, 19, 554-568. [CrossRef] 